\title{
HUBUNGAN PEMBINAAN ORANG TUA DAN PEMBINAAN SISWA DENGAN JIWA KEPEMIMPINAN SISWA DI SMP MUHAMMADIYAH 1 BOGOR
}

\author{
${ }^{1}$ Herlina, ${ }^{2}$ Muhyani, ${ }^{3}$ Zahrotunni'mah \\ 1,2,3 Program Studi Pendidikan Agama Islam \\ Universitas Ibnu Khaldun Bogor \\ Jl. Baru, Kedung Badak, Tanah Sereal, Kota Bogor, Jawa Barat 16162 \\ Email: ${ }^{1}$ Herlina.nha56@gmail.com, ${ }^{2}$ muhyani@gmail.com, ${ }^{3}$ zahrotunni_mah@gmail.com \\ DOI: $10.29313 /$ tjpi.v7i2.4061 \\ Accepted: September 12th, 2018. Approved: April 9th, 2019. Published: April 9th, 2019
}

\begin{abstract}
This study aims to determine the relationship of parental guidance and coaching students with the leadership spirit of students in Mubammadiyah 1 Junior High School, Bogor City. This study uses quantitative methods. The design of this study is correlation research. The subjects in this study were students of Bogor 1 Muhammadiyah Middle School whose population amounted to 430 students with a total sample of $25 \%$ of the total population of 125 students. Data collection was carried out using questionnaire instrument 3 variable X1, namely Parenting and X2 variables, namely student coaching in school and variable $Y$, namely the soul of $V$ ain leadership. To find out the relationship between parenting and fostering students with the leadership spirit of students in school, using the multiple correlation formula. Multiple Correlations. The results of the correlation coefficient between the three variables namely the magnitude of $r_{-}$count (ie $=0.235$ ) the amount between 0.41-0.60 means that the positive correlation between variables $X 1, X 2$ and $Y$ includes a weak correlation in parental education and coaching in schools with a leadership spirit. So it can be concluded that based on data analysis obtained from this study there is a significant correlation between parental exemplary and religious fostering in schools with a religious awareness of students at the City of Bogor 1 Junior High School.
\end{abstract}

Keywords: Fostering Parents, Guiding Students, Student Leadership Spirit.

\begin{abstract}
ABSTRAK
Penelitian ini bertujuan untuk mengetahui hubungan pembinaan orang tua dan pembinaan siswa dengan jiwa kepemimpinan siswa di SMP Muhammadiyah 1 Kota Bogor. Penelitian ini menggunakan metode kuantitatif. Rancangan penelitian ini adalah penelitian korelasi. Subyek dalam penelitian ini adalab siswa SMP Muhammadiyah 1 Kota Bogor yang populasinya berjumlah 430 siswa dengan jumlah sampel 25\% dari jumlah populasi yaitu 125 siswa. Pengumpulan data yang dilakukan dengan instrument angket 3 variabel $X_{1}$, yaitu Pembinaan orang tua dan variable $X_{2}$, yaitu pembinaan siswa di sekolah dan variabel $Y$, yaitu Jiwa kepemimpinan siawa. Untuk mengetahui hubungan antara pembinaan orang tua dan pembinaan siswa dengan jiwa kepemimpinan siswa di sekola menggunakan rumus kolerasi berganda. Hasil koefisien kolerasi antara tiga variabel Yaitu besarnya $r_{\text {hitung }}(y a i t u=0,235)$ yang besarny a antara 0,41-0,60 berarti korelasi positif antara variabel $X 1, X 2$ dan Y termasuk korelasi lemah dalam pendidikan orang tua dan pembinaan di sekolah dengan jiwa kepemimpinan. Maka dapat disimpulkan bahwa berdasarkan analisis data yang diperoleh dari penelitian ini adalah terdapat korelasi yang signifikan antara keteladanan orang tua dan pembinaan keagamaan di sekolah dengan kesadaran beragama siswa di SMPN 1 Kota Bogor.
\end{abstract}

Kata Kunci: Pembinaan Orang Tua, Pembinaan Siswa, Jiwa Kepemimpinan Siswa. 


\section{PENDAHULUAN}

Pada dasarnya sebuah pendidikan dapat dilakukan melalui tiga jalur yaitu jalur keluarga, pendidikan formal, dan masyarakat. Ketiga jalur tersebut harus saling mendukung sebagai satu kesatuan dalam usaha pembentukan kepribadian anak. Proses pendidikan dapat dimaknai sebagai serangkaian kegiatan yang akan terjadi secara berkesinambungan dan tidak cukup hanya selesai dalam satu waktu. Dari situlah proses pendidikan pada setiap individu memerlukan kondisi yang senantiasa mendidik, membimbing, dan mengarahkan.

Pendidikan juga dapat diartikan sebagai bimbingan atau didikan secara sadar oleh pendidik terhadap perkembangan peserta didik, baik jasmani maupun rohani menuju terbentuknya kepribadian yang utama. ${ }^{1}$

Berita-berita miris mengenai kenakalan remaja saat ini menyebabkan berkuranganya penghargaan terhadap nilainilai kemanusiaan, penyusutan demi penyusutan moral terjadi setiap tahunnya khususnya bangsa indonesia, masih banyak keluarga atau orang tua yang tidak begitu peduli akan perkembangan anaknya sehingga seorang anak tidak mampu untuk menghadapi pergaulan-pergaulan bebas yang semakin marak karena kurangnya perhatian serta bingbingan dari orang tuanya, sehingga orang tua dapat dikatakan gagal dalam proses mendidik anaknya dan Penyebab Maraknya Pergaulan Bebas Remaja Indonesia

Orang tua memiliki peranan penting dalam meletakan dasar-dasar disiplin dari pada anak. Orang tua merupakan pendidikan utama dan pertama bagi anak-anak mereka, karena dari merekalah anak mula-mula menerima pendidikan².

\footnotetext{
1 Syamsul Kurniawan, Filsafat Pendidikan Islam, Madani: Malang, 2017, h..6

2 Prof. Dr. H. Jalaluddin, Ibu Madrasah Umat: Fungsi dan Peran Kaum Ibu Sebagai Pendidikan Kodrati, Jakarta: Kalam Mulia, 2016, h..265
}

Selain itu Keluarga juga merupakan lingkungan pendidikan yang pertama, karena dalam keluarga, anak pertama-tama mendapatkan didikan dan bimbingan. Juga ikatan lingkungan yang utama, karena sebagian besar dari kehidupan anak adalah di dalam keluarga, sehingga pendidikan yang paling berpengaruh dan banyak diterima oleh anak adalah dalam keluarga (Hasbullah, 2005:38). Adapun mendidik dengan memberi keteladanan memiliki dasar sebagaimana ayat-ayat Al-Qur'an yang menerangkan tentang dasar-dasar pendidikan untuk menjadikan Rasulullah SAW sebagai role model dalam hal keteladanan. Sebagaimana firman Allah SWT dalam (QS. Al-Ahzab ayat 21):

Artinya "Sesunggubnya telah ada pada (diri) Rasulullah itu suri teladan yang baik bagimu (yaitu) bagi orang yang mengharap (rahmat) Allah dan (kedatangan) hari kiamat dan dia banyak menyebut Allab”. (QS.Al-Ahzab/33:21)

Namun peran pendidikan seorang anak tidak hanya di perankan dari ligkungan keluarga saja, tetapi lingkungan pendidikan formal atau sebuah lembaga sekolahpun menjadi faktor pendorong bagi proses perkembangan serta membantu perkembangan peserta didik, sesuai dengan kebutuhan, potensi, bakat, dan minat mereka melalui kegiatan yang secara khusus diselenggarakan oleh pendidik dan atau tenaga kependidikan yang berkemampuan dan berkewenangan di sekolah.

Adapun tujuan kegiatan pembinaan kesiswaan adalah sesuai dengan yang tercantum dalam Permendiknas No. 39 Tahun 2008, yaitu: a). Mengembangkan potensi siswa secara optimal dan terpadu yang meliputi bakat, minat dan kretivitas; b). Memantapkan kepribadian siswa untuk mewujudkan ketahanan sekolah sebagai lingkungan pendidikan sehingga terhindar dari usaha dan pengaruh negatif dan bertentangan dengan tujuan pendidikan; c). Mengaktualisasikan potensi siswa dalam pencapaian prestasi unggulan sesuai bakat dan minat; d). Menyiapkan siswa agar menjadi warga masyarakat yang berakhlak 
mulia; dan d). demokratis, menghormati hakhak asasi manusia dalam rangka mewujudkan masyarakat madani. ${ }^{3}$

Adanya indikasi kuat mengenai hilangnya nilai-nilai luhur yang melekat pada bangsa Indonesia saat ini, seperti kejujuran, kesantunan, kepedulian dan tolong menolong antar sesama manusia cukup menjadi keprihatinan bersama. Oleh karena itu, harus lebih di usahakan nilai-nilai tersebut agar lebih di tanamkan kepada peserta didik dapat lebih bertanggung jawab terhadap tugas-tugasnya sebagai khalifah di muka bumi ini. Terkait dengan sebuah kepemimpinan seorang anak di tuntut untuk dapat memimpin baik untuk dirinya sendiri maupun orang lain.

Sedangkan Kepemimpinan itu sendiri merupakan sebuah potensi yang ada bagi setiap individu. Seseorang disebut sebagai pemimpin bukan dari jabatan, akan tetapi dari kemampuan untuk mengendalikan diri. Proses awal sukses dalam kepemimpinan berawal dari diri sendiri dan dimulai dari halhal kecil. Upaya awal dalam program ini yakni mengajak siswa untuk memahami dan menyadari tentang pentingnya memiliki kesadaran jiwa kepemimpinan. Siswa akan memperoleh pembinaan secara rutin berkenaan dengan konsep-konsep dasar kepemimpinan. Kemudian siswa juga akan diajak untuk mengaplikasikannya melalui simulasi dari kehidupan sehari-hari di lingkungan sekolah. ${ }^{4}$

Sedangkan Kepemimpinan itu sendiri merupakan sebuah potensi yang ada bagi setiap individu. Seseorang disebut sebagai pemimpin bukan dari jabatan, akan tetapi dari kemampuan untuk mengendalikan diri. Proses awal sukses dalam kepemimpinan berawal dari diri sendiri dan dimulai dari halhal kecil. Upaya awal dalam program ini yakni mengajak siswa untuk memahami dan menyadari tentang pentingnya memiliki

${ }^{3}$ http://budisma1.blogspot.co.id/2011/07/ pendidikan-karakter-melalui-kegiatan.html. Diakses tanggal 20, April,2018

4 Bimo walgito, psikologi sosial,Yogyakarta : CV Andi offset. 2008, h...103 kesadaran jiwa kepemimpinan. Siswa akan memperoleh pembinaan secara rutin berkenaan dengan konsep-konsep dasar kepemimpinan. Kemudian siswa juga akan diajak untuk mengaplikasikannya melalui simulasi dari kehidupan sehari-hari di lingkungan sekolah. ${ }^{5}$

Maka dari itu banyak paktor yang mempengaruhi terbentuknya karakter peserta didik baik oleh lingkungan keluarga, masyarakat maupun lingkungan sekolah sehingga dapat mempengaruhi tercapainya suatu tujuan sebuah pendidikan dalam membentuk kepemimpinan seorang anak disekolah serta mengembangkan peserta didik melalui pembinaan spiritual yang sesuai dengan ajaran agama islam.

\section{KERANGKA TEORITIS}

\section{Pengertian Pembinaan Orang Tua}

$$
\text { Menurut Zuriah }
$$

pembinaan dapat diartikan sebagai kegunaan yaitu merubah sesuatu sehingga menjadi baru yang memiliki nilai-nilai yang tinggi. Dengan demikian pembinaan juga mengandung makna sebagai pembaharuan, yaitu melakukan usaha-usaha untuk membuat sesuatu menjadi lebih sesuai atau cocok dengan kebutuhan dan menjadi lebih baik dan lebih bermanfaat. Dari beberapa pendapat di atas dapat dikatakan bahwa pembinaan merupakan usaha dengan membimbing dan membentuk sesuatu untuk berubah ke arah yang lebih baik atau lebih bermanfaat. ${ }^{6}$

Keluarga juga merupakan institusi pertama dalam masyarakat sebagai tempat pertama bagi setiap individu dalam meniti kehidupannya, tempat terjadinya interaksi antara individu dengan lingkungan terdekat.

${ }^{5}$ Bimo walgito, psikologi sosial,Yogyakarta : CV Andi offset. 2008, h...103

6 Agus Yunita,Saiful Usman dan Hasbi Ali "Peran keluarga dalam pembinaan budi pekerti usia sekolab dasar". Jurnal ilmiah mahasiswa pendidikan kewwarganegaraan unsyiah, volume 1, No 1: 1-12 Agustus 2016 
Keluarga merupakan tempat belajar pertama dalam berbahasa, berperilaku, menumbuhkan kecenderungan psikologis, kepribadian dan sosial. Melihat pentingnya peran keluarga, maka wajib bagi setiap kaum Muslimin untuk membangun keluarga atas dasar kebenaran, keadilan, kasih-sayang, tolong-menolong, dan saling hormat menghormati yang dibangun harus berdasarkan iman. Sistem kekeluargaan yang diakui oleh Islam adalah sistem "al usrah azzaujiah yaitu keluarga yang terdiri atas suami dan istri yang dibangun atas dasar pernikahan yang sah menurut syariah Islam. ${ }^{7}$

\section{Macam-macam Pembinaan}

Salah satu aspek terpenting dalam hubungan kelekatan orang tua dan anak adalah pola asuh. Ada beberapa macam pola asuh orang tua terhadap anak yang dikaitkan dengan aspek-aspek yang berbeda dalam tingah laku sosial anak, yaitu otoritatif, otoriter, permisif dan autoritatif.

\section{Pembinaan Otoritatif}

Merupakan salah satu gaya Pembinaan atau pola asuh oang tua yang memerlihatkan pengawasaan ekstra ketat terhadap tingkah laku anak, tetapi orang tua juga bersifat responsive, menghargai dan menghormati pemikiran, perasaan, serta mengikut sertakan anak dalam mengambil sebuah keputusan. ${ }^{8}$

\section{Pembinaan Otoriter}

Pola Pembinaan ini merupakan suatu pola Pembinaan dimana orang tua membatasi dan menuntut anak untuk mengikuti perintah-perintah orang tua. Orang tua yang otoriter cenderung

7 Dr.muhyani, pengarub Pembinaan orang tua dan peran guru disekolah menurut persepsi murid terbadap kesadaran religius dan kesehatan mental, 2012, jakarta pusat, hlm 101

8 Nurfaleni, Artikel Macam-Macam Pembinaan Orang Tua, 20 Mei 2015 membatasi dengan tegas suatu aturan dalam rumah, dan orang tua dengan pola Pembinaan ini cenderung tidak memberikan dan menghargai pendapat yang diberikan oleh anak. Serta orang tua tidak bersikap demokratis kepada anak.

\section{Pembinaan Permasif}

Orang tua yang menerapkan model Pembinaan permisif atau pemanja biasanya memberikan pengawasan yang sangat longgar. Memberikan kesempatan pada anaknya untuk melakukan sesuatu tanpa pengawasan yang cukup dari orang tua. Mereka cenderung tidak menegur atau memperingatkan apabila anaknya sedang dalam bahaya, dan sangat sedikit bimbingan yang diberikan oleh mereka. ${ }^{10}$

\section{Pembinaan Autoritatif}

Pembinaan yang memprioritaskan kepentingan anak, akan tetapi tidak ragu-ragu mengendalikan mereka. Orang tua dengan Pembinaan ini bersikap rasional, selalu mendasari tindakannya pada rasio atau pemikiran-pemikiran. Orang tua tipe ini juga bersikap realistis terhadap kemampuan anak, tidak berharap yang berlebihan yang melampaui kemampuan anak. ${ }^{11}$

\section{Pembinaan dalam Perspektif Islam}

\section{Abdullah Nashih Ulwan}

mengemukakan tanggung jawab orang tua atas anak terdiri atas: a). Tanggung jawab pendidikan Iman adalah mengikat anak dengan dasar-dasar keimanan sejak anak mampu berkomunikasi, membiasakannya dengan rukun Islam sejak anak memahami, dan mengajarkan kepada anak dengan dasar-

${ }^{9}$ Ibid

10 Muhyani, Pengaruh Pembinaan Orang tua Dan Peran Guru Di Sekolah Menurut Persepsi Murid Terbadap Kesadaran Religius Dan Kesehatan Mental, Peneerbit : Kementrian Agama Republik Indonesia. Jakarta, 2012, hal..86

11 Ibid, h..84 
dasar Syariah; b). Tanggung jawab pendidikan moral adalah serangkaian prinsip dasar moral dan keutamaan sikap serta watak (tabiat) yang harus dimiliki dan dijadikan kebiasaan oleh anak yang merupakan buah iman yang kuat dan pertumbuhan sikap keberagamaan yang benar sejak masa pemula hinggga ia menjadi seorang mukalaf, yaitu siap mengarungi lautan kehidupan.

c). Tanggung jawab pendidikan fisik adalah agar anak-anak tumbuh dewasa dengan kondisi fisik yang kuat, sehat, bergairah, dan bersemangat. Termasuk dalam tanggung jawab orang tua atas anak adalah menyediakan makanan dan minuman yang sehat dan halal, menyediakan pakaian yang sesuai dengan syariah Islam, menyediakan tempat tinggal yang baik dan sehat, mendidik pola hidup sehat, mendidik agar tidak menyakiti diri sendiri dan orang lain, membiasakan anak berolah raga dan berlatih ketangkasan, membiasakan anak tidak larut dalam kenikmatan materi, membiasakan anak hidup positif dan produktif (tidak merokok, menjaga kemaluan tidak berzina dan homoseksual, tidak terlibat minuman keras dan narkotika);

d). Tanggung jawab pendidikan intelektual adalah membentuk pola pikir anak dengan segala suatu yang bermanfaat, seperti: ilmu-ilmu agama, kebudayaan, dan peradaban;

e). Tanggung jawab pendidikan mental adalah untuk mendidik anak semenjak mulai mengerti supaya bersikap berani, terbuka, mandiri, suka menolong, bisa mengendalikan amarah, dan senang kepada seluruh bentuk keutamaan jiwa dan moral secara mutlak, dan terhindar dari sifatsifat buruk (minder, penakut, kurang percaya diri, dengki, dan pemarah);

f). Tanggung jawab pendidikan sosial adalah mendidik anak sejak kecil agar terbiasa menjalankan perilaku sosial yang utama, dasar-dasar kejiwaan yang mulia yang bersumber pada akidah Islamiyah yang kekal dan kesadaran iman yang mendalam, agar di tengah-tengah masyarakat nanti ia mampu bergaul dan berperilaku sosial yang baik, memiliki keseimbangan akal yang matang dan tindakan yang bijaksana.

Seperti firman Allah dalam (Q.S.

Lukman ayat 13-18), yang artinya:

"Dan (ingatlah) ketika Luqman berkata kepada anaknya, di waktu ia memberi pelajaran kepadanya: "Hai anakku, janganlah kamu mempersekutukan Allah, Sesunggubnya mempersekutukan (Allah) adalab benar-benar keraliman yang besar".

Ayat-ayat tersebut menunjukan bahwa Pembinaan dalam konsep islam memang tidak menjelaskan bagaimana gaya Pembinaan yang terbaik atau yang lebih baik, namun seharusnya dilakukan oleh orang tua yang tergantung kondisi anak dan karakter anak serta mengikuti perkembangan jaman.

Adapun yang berkaitan dengan Pembinaan orang tua, menurut Abdullah Nasi Ulwan memaparkan tentang kaidahkaidah pendidikan yang efektif dalam pendidikan anak adalah:

\section{Pendidikan dengan Keteladanan}

Abdul Nasi Ulwan mengungkapkan bahwa keteladanan dalam pendidikan adalah metode yang paling meyakinkan keberhasilannya dalam mempersiapkan dan membentuk anak di dalam moral, spiritual dan sosial. ${ }^{12}$

\section{Pendidikan dengan Adat Kebiasaan}

Salah satu ketetapan dalam ajaran islam adalah setiap manusia diciptakan oleh allah dengan fitrah tauhid yang murni, agama yang lurus dan iman kepada Allah. Sehingga setiap anak yang dilahirkan membawa potensi, salah satunya berupa potensi beragama, yaitu agama tauhid. . ${ }^{13}$

12 Muhyani, Pengaruh Pembinaan Orang tua Dan Peran Guru Di Sekolah Menurut Persepsi Murid Terbadap Kesadaran Religius Dan Kesehatan Mental, Peneerbit : Kementrian Agama Republik Indonesia.

akarta, 2012, hal..87

13 Ibid h.89 


\section{Pendidikan dengan Nasihat}

Agar pendidikan dengan metode ini efektif, pemberi nasehat seharusnya orang yang berwibawa di mata anak. Dan pemberi nasehat dalam keluarga tentunya orang tuanya sendiri selaku pendidik bagi anakanaknya. ${ }^{14}$

\section{Pendidikan dengan Memberikan Perhatian}

Pendidikan dengan perhatian adalah mecurahkan,memperhatikan dan senantiasa mengikuti perkembangan anak dalam pembinaan akhlak dan moral, persiapan spiritual dan sosial disamping selalu bertanya tentang situasi pendidikan jasmani dan daya hasil ilmiahnya. ${ }^{15}$

\section{Pembinaan dan Tahap Perkembangan}

Anak adalah investasi orang tua dimasa depan, oleh karena itu mereka perlu dipersiapkan agar kelak menjadi sumber daya manusia yang berkualitas, sehat, bermoral dan berguna bagi masyarakat, untuk itu perlu dipersiapkan sejak dini, sejak dalam kandungan melalui Pembinaan yang baik. Faktor-faktor yang mempengaruhi perkembangan anak:

\section{Faktor Bawaan}

Faktor bawaan merupakan warisan dari sifat ayah/ibu atau pengaruh ketika anak berada dalam kandungan, misalnya pengaruh gizi, penyakit dan lain-lain. ${ }^{16}$

\section{Faktor Lingkungan}

Faktor lingkungan meliputi suasana dan cara pendidikan lingkungan tertentu, lingkungan rumah atau keluarganya, serta

14 Ibid h..91

${ }^{15}$ Ibid h..94

16 Hasnida, M.Pd., Analisis Kebutuban anak usia dini, PT Luximia Metro Media: Jakarta, 2015, h.106 sarana dan prasarana yang tersedia (alat bermain dan lapangan bermain). Pembinaan di lingkungan keluarga ini diarahkan pada bagaimana upaya untuk mengembalikan fungsi dan peran ibu ke nilai-nilai ajaran islam. Bukan atas dasar tradisi masyarakat yang berlaku. ${ }^{17}$

\section{Pembinaan di Sekolah}

Pembinaan disekolah pada hakikatnya adalah pengganti Pembinaan orang tua di luar rumah, yang berperan untuk melanjutkan estafet Pembinaan dan pendidikan orang tua di rumah untuk menciptakan peserta didik yang mempunyai Jiwa kepemimpinan.

Pengertian pembinaan di sekolah. Secara bahasa arti dari pembinaan adalah merubah. Syeikh Taqiyuddin An-Nabhani mengartikan istilah pembinaan ini dengan "taskif"18 yang artinya adalah merubah pemikiran seseorang yang tadinya sekuler menjadi islam, merubah pemikiran seseorang yang tadinya liberal menjadi Islam, menjadikannya kader yang mau berdakwah dan terjun kemasyarakat.

Tujuan dari pembinaan di sekolah ialah merubah pola pikir peserta didik menjadi pola pikir yang Islami dalam ranah lingkungan di sekolah. Oleh karnanya peran guru di sekolah sangat mempengaruhi karateristik siswa, yang kemudian siswa pun akan meniru karateristik yang dilakukan orang guru di sekolah.

\section{Peran Guru}

Di sekolah, guru adalah orang tua kedua bagi anak didik. Sebagai orang tua, guru harus menganggapnya sebagai anak didik, bukan menganggapnya peserta didik. Ketika guru hadir bersama-sama anak didik di sekolah, di dalam jiwanya seharusnya

17 Prof. Dr. H. Jalaluddin, Ibu Madrasah Umat: Fungsi dan Peran Kaum Ibu Sebagai Pendidikan Kodrati, Jakarta: Kalam Mulia, 2016, h..316

18 Taqiyuddin An-Nabhani, At-takattulul hizbi, beirut, 2003, hlm 67 
sudah tertanam niat untuk mendidik anak didik agar menjadi orang yang berilmu pengetahuan, mempunyai sikap dan watak yang baik, yang cakap dan terampil, bersusila dan berakhlak mulia. Adapun peran guru dan dosen menurut Elfindri adalah:

Semakin mudahnya siswa dan mahasiswa menggali ilmu Allah melalui metode belajar dan mengajar yang diberikan oleh sang guru dan dosen. Sehingga proses yang dilalui di sekolah atau bangku kuliah adalah mencoba menggali ilmu sedalamdalamnya, kemudian mengembangkan sendiri.

Mampu mencontohkan value, nilainilai universal yang baik yang dimiliki guru dan dosen kepada anak didik atau mahasiswa, nilai-nilai tersebut sesunggguhnya juga datangnya dari Sang Pencipta, seperti kreatif, tanggung jawab, inovatif, teliti dan bijaksana dalam menata alam ciptaan-Nya.

\section{Kepemimpinan Siswa di Sekolah}

"Pemimpin" dan "Kepemimpinan itu berarti berasal dari kata "Pimpin". Kata Pimpin mengandung beberapa arti yaitu memelopori , berjalan di muka, menuntun, Membingbing, Mendorong bergerak lebih awal. ${ }^{19}$

\section{Sedangkan Pembinaan Sikap} Kepemimpinan memiliki arti sebuah kegiatan atau usaha dalam rangka memberikan bimbingan serta arahan untuk membangun komunikasi yang baik dalam sebuah organisasi, agar dapat mempengaruhi, menggerakkan serta mengarahkan suatu tindakan pada diri seseorang atau sekelompok orang, untuk mencapai tujuan dalam sebuah organisasi. Karena dalam sebuah organisasi terdapat pengikut dan diperlukan pembinaan dalam mengarahkan para pengikut dalam mencapai sebuah tujuan organisasi. Adapun untuk mewujudkan seseorang menjadi pemimpin yang ideal

19 Drs.K.Permadi,S.H, Pemimpin dan Kepemimpinan dalam Manajemen, Jakarta : Rineka Cipta, 2010., h...9 harus memahami lebih dalam tentang ciri-ciri pemimpin. Menurut Irham Fahmi yang mengutif dari george R.Terri mengemukakan 8 ciri dari pemimpin yaitu:

a). Energi: Mempunyai kekuatan mental dan fisik; b). Stabilitas Emosi: Seorang pemimpin tidak boleh berprasangka jelek terhadap bawahannya, ia tidak boleh cepat marah dan percaya pada diri sendiri harus cukup besar; c). Human relationship : Mempunyai pengetahuan tentang hubungan manusia; d). Personal Motivation : Keinginan menjadi pemimpin harus lebih besar dan dapat memotivasi dirinya sendiri;

e). Comunication Skill : Mempunyai kecakapan untuk berkomunikasi; f). Teaching Skill : mempunyai kecakapan untuk mengajarkan menjelaskan dan mengembangkan bawahannya; g). Social Skill : Mempunyai keahlian di bidang sosial, supaya terjamin kepercayaan dan kesetiaan bawahannya. Ia harus suka menolong, senang jika bawahannya maju, peramah serta luwes dalam pergaulan; dan $\mathrm{h}$ ). Technical compettent : Mempunyai kecakapan dalam menganalisis, merencanakan, mengorganisasi, mendelegasikan wewenang, pengambilan keputusan dan mampu menyusun konsep. ${ }^{20}$

\section{Jiwa Kepemimpinan}

Menjadi seorang pemimpin dengan memiliki jiwa kepemimpinan yang tinggi tentunya tidak mudah dan membutuhkan proses yang sangat panjang. Namun, untuk menacapai keberhasilan dalam memimpin orang lain, seseorang harus senantiasa mau berusaha untuk mengasah potensinya setiap hari. setiap orang tidak akan tumbuh dan berhasil, jika tidak mau berubah dan menyadari kesalahannya.

Menurut Earl Nightingale dan Whitt Schult dalam bukunya Creative Thingking How to win Ideas (Kartini, 2011: 36) menuliskan kemampuan pemimpin dan

$20 \quad$ Irham Fahmi, Manajemen
Kepemimpinan Teori dan Aplikasi, Bandung : Alfabeta, 2012., h...19-20 
syarat yang harus dimiliki seorang pemimpin adalah:

a). Kemandirian, bertanggungjawab dan berhasrat memajukan diri sendiri (individualism); b). Besar rasa ingin tahu, dan cepat tertarik pada manusia dan bendabenda; c). Multiterampil atau memiliki kepandaian beraneka ragam; d). Memiliki rasa humor, antusiasme tinggi, suka berkawan; e). Perfeksionis, selalu ingin mendapatkan yang sempurna; f). Mudah menyesuaikan diri, adaptasinya tinggi; g). Sabar namun ulet, serta tidak "mandek" berhenti; h). Waspada, peka, jujur, optimistis, pemberani, gigih, ulet, realistis; i). Komunikatif, serta pandai berbicara atau berpidato; j). Berjiwa wiraswasta; k). Sehat jasmaninya; l). Dinamis; $\mathrm{m})$. Sangggup dan suka menerima tugas yang berat, serta berani mengambil resiko; $n$ ). Tajam firasatnya, tajam, dan adil pertimbangannya; o). Berpengetahuan luas, dan haus akan ilmu pengetahuan; p). Memiliki motivasi tinggi dan menyadari target atau tujuan hidupnya yang ingin dicapai, dibimbing oleh idealisme tinggi; q). Punya imajinasi tinggi, daya kombinasi, dan daya inovasi. ${ }^{21}$

\section{Sikap Kepemimpinan}

Sikap kepemimpinan adalah suatu sikap pribadi yang mampu mengembangkan potensi diri, mampu menempatkan diri serta mampu berfikir terbuka dan positif terhadap diri dan lingkungan. Adapun sikap kepemimpinan ini tidak hadir dengan sendirinya melainkan dibangun dan dibentuk oleh pilar-pilar pendidikan yaitu keluarga, sekolah dan masyarakat.

\footnotetext{
21 Mei Shinta, Judul skripsi "Implementasi pembinaan kepemimpinan siswa di sekolah menengah atas (SMA) Negri 3 Yogyakarta : Yogyakarta, 2015, hal. 26
}

\section{Hubungan Pembinaan Orang Tua dan Pembinaan Siswa dengan Jiwa Kepemimpinan Siswa di Sekolah}

Berdasarkan kajian pustaka di atas dapat dikatakan bahwa setiap anak yang menjalani proses pendidikan karakter sangat memerlukan pembinaan yang baik dari orang tua mereka, karena metode yang cukup besar pengaruhnya dalam mendidik anak adalah dengan cara pemberikan pembinaan. Anak memerlukan pembinaan yang baik karena anak senantiasa akan meniru apa yang dilakukan orang tua serta lingkungan mereka. pembinaan orang tua dalam membentuk jiwa kepemimpinan yang terus diberikan arahan oleh orang tua mereka, agar mereka dapat menumbuhkan jiwa kepemimpinan mereka.

Selain merupakan faktor pembawaan (fitrah), sikap kepemimpinan juga ditumbuhkan melalui lingkungan, salah satunya merupakan lingkungan keluarga. Disamping lingkungan keluarga, lingkungan sekolah juga ikut berperan penting dalam menumbuhkan jiwa kepemimpinan anak. Karena sekolah merupakan fungsi kontrol lanjutan setelah pembinaan orang tua dirumah, tanpa adanya keselarasan pengajaran guru dan orang tua dengan pihak sekolah, maka jiwa kepemimpinan anakpun akan sulit ditumbuhkan.

Sebagaimana pembinaan orang tua dalam pembentukan kemandirian anak melaksanakan perintah agama dirumah, sekolahpun menjadi faktor pendukung yang senantiasa mengontol serta memberikan pembinaan kemandirian agar anak terbiasa melaksanakan apapun perintah agama serta mejauhi segala larangan agama, dan membuat anak terbiasa melakukan perilakuperilaku baik dan mandiri tanpa adanya paksaan yang kemudian akan menumbuhkan jiwa kepemimpinan pada anak tersebut.

\section{METODE PENELITIAN}

Dalam pelaksanaan penelitian ini, peneliti menggunakan pendekatan 
kuantitatif. Rancangan penelitian ini adalah penelitian korelasi. Peneliti mencari hubungan antara variabel $\mathrm{X}_{1}$, yaitu keteladanan orang tua dan variable $\mathrm{X}_{2}$, yaitu pembinaan guru di sekolah dengan variabel $Y$, yaitu jiwa kepemimpinan siswa.

Dalam penelitian ini peneliti bermaksud meneliti hubungan pembinaan orang tua dan pembinaan siswa di sekolah terhadap jiwa kepemimpinan siswa. Dengan kata lain, apakah pembinaan orang tua dan pembinaan siswa di sekolah terhadap jiwa kepemimpinan siswa.

Penelitian ini dilakukan di Sekolah Menengah Pertama Muhammadiyah 1 Kota Bogor yang beralamat di Jln. Pahlawan Gg. Raden saleh No.55 Kota Bogor. Adapun waktu pelaksanaan penelitian dari bulan juli 2018 sampai dengan bulan agustus 2018.

Populasi pada penelitian ini adalah pelajar yang saat ini sedang belajar di kelas 7 A,B,C,D,kelas 8 A,B,C,D,E,F dan kelas 9 A,B,C di SMP Muhammadiyah 1 Kota Bogor tahun pelajaran 2018-2019 dengan jumlah 431 siswa. Adapun subjek dalam penelitian ini sampelnya $29 \%$ dari 480 siswa kelas 7 A,B,C,D SMP Muhammadiyah 1 Kota Bogor tahun pelajaran 2018-2019, dengan jumlah sampel $29 \% \times 431=125$ siswa.

Dalam pengumpulan data, penelitian ini menggunakan instrumen angket, angket merupakan suatu teknik atau cara pengumpulan data secara tidak langsung. Angket berisi sejumlah pertanyaan atau pernyataan yang harus dijawab yang harus direspon oleh responden. ${ }^{22}$

Untuk menguji hipotesis penelitian dilakukan analisis data menggunakan korelasi berganda $(\mathrm{F}<0.005)$ untuk melihat signifikasi korelasi antara skor masingmasing item dengan skor total (item total correlation), sehingga akan diketahui kekuatan setiap item dalam mengukur apa yang

22 Sudaryono, Aplikasi Statistik untuk Penelitian, Jakarta: Lentera Ilmu Cendikia, 2014, h.45 hendak diukur. ${ }^{23}$ Metode ini digunakan untuk mendapatkan data pokok tentang bagaimana pembinaan orang tua, dan pembinaan siswa di sekolah berpengaruh terhadap jiwa kepemimpinan siswa. Analisis data yang penulis lakukan adalah menggunakan korelasi ganda $\left(\mathrm{Rx}_{1} \mathrm{x}_{2 \mathrm{y}}\right)$.

\section{HASIL PENELITIAN DAN PEMBAHASAN}

Langkah pertama yang harus ditempuh adalah terlebih dahulu mencari $\mathrm{df}$ (degree of freedom) atau derajat kebebasan, dengan rumus $\mathrm{df}=\mathrm{N}$-nr. Responden yang diteliti yakni sebanyak 125 orang, dengan $\mathrm{N}=125$. Variabel yang penulis cari korelasinya adalah variabel $\mathrm{X}$ dan $\mathrm{Y}$, jadi $\mathrm{nr}=2$. Dapat diperoleh df-nya yaitu $\mathrm{df}=\mathrm{N}-2$ $=125-2=123$. Setelah diketahui $\mathrm{df}=123$ kemudian berkonsultasi pada tabel " $r$ " Maka $\mathrm{r}$ tabel taraf siginifikan 5\% 0,05 dan $\mathrm{r}$ hitung $\quad 0,235 \quad 23,5 \%$. Dengan membandingkan $r_{\text {hitung }}$ dan $r_{\text {tabel, }}$, ternyata $r_{\text {hitung }}$ lebih besar daripada $r_{\text {tabel }}$ baik pada taraf signifikan $5 \%$ ataupun $23,5 \%$,

hasil interpretasi nilai yang lebih teliti, maka peneliti uji hipotesis dengan melihat nukilan tabel koefisien korelasi $r_{S P S S}$. Dengan df sebesar 124 diperoleh dari $r_{\text {tabel }}$ pada taraf signifikan 5\% sebesar 0,05 sedangkan pada taraf signifikan 23,5\% diperoleh $r_{\text {tabel }}$ sebesar 0,235 ternyata $r_{\text {hitung }}$ lebih besar dari pada $r_{\text {tabel }}$ baik pada taraf signifikan $5 \%$, sehingga hipotesis nol (ho) ditolak, dan hipotesis alternatif (ha) diterima. Dapat disimpulkan bahwa terdapat pengaruh positif yang signifikan antara pola asuh orang tua dan pembinaan siswa disekolah dengan jiwa kepemimpinan anak di SMP Muhammdiyah Kota Bogor.

${ }^{23}$ Muhyani, pengarub pengasuban orang tua dan peran guru disekolah menurut persepsi murid terhadap kesadaran religius dan kesehatan mental, 2012, jakarta pusat, hlm 132-133 


\section{KESIMPULAN}

Berdasarkan penelitian yang penulis lakukan, dengan judul yaitu hubungan keteladanan orang tua dan pembinaan siwa di sekolah dengan jiwa kepemimpinan siswa dapat ditarik kesimpulan sebagai berikut:

Tingkat Pembinaan orang tua di SMP Muhammadiyah 1 Kota Bogor tahun ajaran 2018/2019 tersebut terletak pada kualifikasi lemah dengan nilai sebesar 0,235, berada pada nilai person korelasinya 0,210,40

Tingkat pembinaan guru di sekolah SMP Muhammadiyah 1 Kota Bogor tahun ajaran 2018/2019 tersebut terletak pada kualifikasi lemah dengan dengan nilai sebesar 0,235 , berada pada nilai person korelasinya $0,21-0,40$.

Tingkat Jiwa kepemimpinan siswa di SMP Muhammadiyah 1 Kota Bogor tahun ajaran 2018/2019 tersebut terletak pada kualifikasi lemah dengan nilai sebesar 0,235, berada pada nilai person korelasinya 0,21 0,40 .

Terdapat hubungan yang signifikan antara pembinaan orang tua dengan jiwa kepemimpinan siswa di SMP Muhammadiyah 1 Kota Bogor tahun ajaran 2018/2019. Tampak bahwa r hitung 0, 235 lebih besar dari $\mathrm{r}$ tabel 0,05 $(0,235>0,05)$.

Terdapat hubungan yang signifikan antara pembinaan guru di sekolah dengan jiwa kepemimpinan siswa di SMP Muhammadiyah 1 Kota Bogor tahun ajaran 2018/2019. Tampak bahwa r hitung 0,235 lebih besar dari $\mathrm{r}$ tabel $0,05(0,235>$ $0,05)$.

Terdapat hubungan yang signifikan antara pembinaan orang tua dan pembinaan guru di sekolah dengan jiwa kepemimpinan siswa di SMP Muhammadiyah 1 Kota Bogor tahun ajaran 2018/2019. Tampak bahwa $r$ hitung 0,235 lebih besar dari $r$ tabel 0,05 $(0,235>0,05)$. dengan kata lain terdapat hubungan yang lemah antara pembinaan orang tua dan pembinaan guru di sekolah dapat meningkatkan jiwa kepemimpinan siswa di SMP Muhammadiyah 1 Kota Bogor. Dengan demikian dapat disimpulkan bahwasanya tinggi rendahnya jiwa kepemimpinan siswa di SMP Muhammadiyah 1 Kota Bogor dapat dipengaruhi oleh tinggi rendahnya pembinaan orang tua dan pembinaan guru di sekolah.

\section{DAFTAR PUSTAKA}

Agus Yu.nita,Saiful Usman dan Hasbi Ali "Peran keluarga dalam pembinaan budi pekerti usia sekolah dasar". Jurnal ilmiah mahasiswa pendidikan kewarganegaraan unsyiah, volume 1, No 1: 1-12 Agustus 2016

Hasnida, M.Pd., Analisis Kebutuban anak usia dini, PT Luximia Metro Media: Jakarta, 2015

Irham Fahmi, Manajemen Kepemimpinan Teori dan Aplikasi, Bandung : Alfabeta, 2012

Jalaluddin, Ibu Madrasah Umat: Fungsi dan Peran Kaum Ibu Sebagai Pendidikan Kodrati, Jakarta: Kalam Mulia, 2016

Kartono, Kartini . Pemimpin dan Kepemimpinan; Apakah Kepemimpinan Abnormal itu?, (Jakarta: PT. Raja Grafindo Persada, 2001), Cet. IX

Kurniawan, Syamsul. Filsafat Pendidikan Islam. Madani: Malang. 2017.

Mei Shinta, Judul skripsi "Implementasi pembinaan kepemimpinan siswa di sekolah menengah atas(SMA) Negri 3 Yogyakarta : Yogyakarta, 2015

Muhyani, Pengarub Pembinaan Orang tua Dan Peran Guru Di Sekolah Menurut Persepsi Murid Terhadap Kesadaran Religius Dan Kesehatan Mental, Peneerbit : Kementrian Agama Republik Indonesia. Jakarta, 2012

Nurfaleni, Artikel Macam-Macam Pembinaan Orang Tua, 20 Mei 2015

Permadi, K. Pemimpin dan Kepemimpinan dalam Manajemen, Jakarta : Rineka Cipta. 2010. 
Sudaryono. Aplikasi Statistik untuk Penelitian, Jakarta: Lentera Ilmu Cendikia. 2014.

Sugiyono. Statistika untuk Penelitian, Bandung:

Alfabeta. 2017.

Taqiyuddin An-Nabhani, At-takattulul hizbi. beirut, 2003.

Walgito, Bimo. psikologi sosial,Yogyakarta :

CV Andi offset. 2008

http://budisma1.blogspot.co.id/2011/07/p

endidikan-karakter-melalui-

kegiatan.html. Diakses tanggal 20, April, 2018. 